\title{
Use of Ceramic Waste as Filler in Semi-Dense Bituminous Concrete
}

\author{
Electricwala Fatima ${ }^{1}$, Sadanand Sahu², Ankit Jhamb ${ }^{3}$, Rakesh Kumar ${ }^{4, *}$ \\ ${ }^{1}$ Junior Research Scholar, Civil Engineering Department, S.V. National Institute of Technology Surat-395007, Gujarat, India \\ ${ }^{2}$ Post graduate student, TEP Civil Engineering Department, S.V. National Institute of Technology Surat-395007, Gujarat, India \\ ${ }^{3}$ B. Tech (Civil) Student, Civil Engineering Department, S.V. National Institute of Technology Surat-395007, Gujarat, India \\ ${ }^{4}$ Associate Professor, Civil Engineering Department, S.V. National Institute of Technology Surat-395007, Gujarat, India \\ Corresponding author: krakesh@ced.svnit.ac.in
}

Received April 03, 2014; Revised May 07, 2014; Accepted May 07, 2014

\begin{abstract}
The purpose of this paper is to evaluate the suitability of ceramic waste as a filler material in SemiDense Bituminous Concrete. A bituminous concrete mixes with ceramic dust and hydrated lime were prepared in different proportions (3\% and 5\%) as filler. The amount of optimum binder content was determined by Marshall Stability test for samples. The mechanical performance was determined for Marshall Stability, deformation behavior or flow, as well as for density and void characteristics base on prevailing Indian standards specifications. Results show that the stability values and other parameters of samples containing ceramic wastes are improved in comparison to conventional mineral filler. The benefits of using ceramic waste in bituminous concrete mixture as mineral filler (3-5\%) are therefore recommended. The replacement of conventional filler like lime and other mineral in bituminous concrete by ceramic wastes will have major environmental benefits.
\end{abstract}

Keywords: ceramic waste, SDBC, concrete, Marshall Test, optimum binder content

Cite This Article: Electricwala Fatima, Sadanand Sahu, Ankit Jhamb, and Rakesh Kumar, "Use of Ceramic Waste as Filler in Semi-Dense Bituminous Concrete." American Journal of Civil Engineering and Architecture, vol. 2, no. 3 (2014): 102-106. doi: 10.12691/ajcea-2-3-2.

\section{Introduction}

Semi-dense bituminous concrete is the most commonly used pavement material due to its construction procedures. The ever increasing economic cost and lack of availability of natural material have opened the opportunity to explore locally available waste material. If industrial waste materials can be suitably used in road construction, the pollution and disposal problems may be partially reduced. As reported, Indian ceramics industry, which is comprised of wall and floor tiles, sanitary ware, bricks and roof tiles, refractory materials and ceramic materials for domestic and others use is producing approximately 15 to $30 \mathrm{MT}$ per annum waste. The state of Gujarat accounts for around $70 \%$ of total ceramic production in India and out of total production $30 \%$ goes as waste and dumped in the open spaces [1]. The advantages of using ceramic waste dust in road construction as mineral filler are: (i) the ceramic dust available at zero economic cost, (ii) chemical and mechanical properties will be consistent, (iii) road construction activity approaches to become green, (iv) durable, hard and highly resistant to biological, chemical and physical degradation forces [2].

Researches show that potential use of the ceramic wastes in the construction industry is beneficial. Concrete mixtures with ceramic aggregates perform better than the control concrete mixtures concerning compressive strength, workability, capillary water absorption, oxygen permeability and chloride diffusion, thus leading to more durable concrete structures [3]. It was reported that recycled, eco-efficient ceramic aggregate concrete present superior mechanical behavior compared to conventional concrete as it interfere in a negative way during hydration process. In case of flowable concrete, the recycled ceramic aggregates were found more workable and compact than in case of natural aggregate [4]. It was noticed that fine carbonate fillers complement the deficiency in fine particles of the cement's particle size distribution, which enhance both the flow ability and stability of fresh concrete. Ceramic dust gets fill in between the relatively coarser cement grains, reducing the room available for water and consequently the water demand. The contribution of hydroxide and calcium carbonate as a filler in the mixture increases its preserved resistance up to $40 \%$, fulfilling the Indian codal specifications for its application in cement construction work. Furthermore, the filler contribution is demonstrated to improve the adherence between aggregate-bitumen under the effect of water by $45 \%$ [5].

The asphalt dynamic modulus, flow number and indirect tensile strength of hot mix asphalt were showing considerable improvement by adding filler made of ground scrap [6]. Researcher reported that waste tiles also show pozzolanic properties as chemical and physical properties of the cement meets the cement standard up to the addition of $35 \%$ waste tiles [7]. One of the reason to 
use waste materials as filler in the construction is to minimize the uses of natural resources, such as aggregate etc. It was reported that the mechanical and transport properties were improved by using marble powder and limestone filler in self compacting concretes (SCC) [8]. Using granite sludge and andesite mineral filler in bituminous hot mixtures could improve the engineering properties of the mixes in wearing courses [9]. The behavior and effect of pre compaction curing on grade- 2 semi dense bituminous concrete (SDBC-2) mix using bituminous emulsions treated mixtures (BETM) by modified Marshall Method was also studied. The results shows that mix with cement and hydrated lime as filler each 2\% both showed better results for dry and wet Marshall Stability, Marshall Flow and ITS (Indirect Tensile Strength) compared to mix with no filler [10]. Addition of Copper Slag (CS) as fine aggregate (up to $30 \%$ ) in various bituminous mixes like Bituminous Macadam, Dense bituminous Macadam, Bituminous Concrete and Semi-Dense Bituminous Concrete provides good interlocking and eventually improves volumetric and mechanical properties of bituminous mixes [11].

Considering the effectiveness of ceramic waste in cement concrete work, in this paper ceramic waste was studied in bituminous concrete as mineral filler for road construction work. In this study, the usability of optimum percentage of ceramic wastes was investigated in the semi-dense bituminous concrete mixes. To achieve the objective, Marshall Stability mixes were prepared containing different proportion of ceramic dust and hydrated lime. The waste material proportion was experimented as per the Indian codal provision to check its mechanical properties and durability for bituminous layer.

\section{Materials and Experiments}

\subsection{Materials}

Crushed quartzite aggregate was used as coarse aggregate $(20 \mathrm{~mm}$ and $10 \mathrm{~mm})$ in this experimental investigation. Aggregates were obtained from Chikhli local quarry around Surat city, in the state of Gujarat, India. The sizes of aggregate and stone dust were used as per specification (MORTH 2013).

Aggregate material tests were carried out based on Indian standards, in order to ascertain the physical and mechanical properties of the material to be used in the samples of Marshall Stability mixtures. The physical properties of the aggregate are shown in the Table 1.

Table 1. Properties of Coarse Aggregate and Fine Aggregate

\begin{tabular}{|c|c|c|c|}
\hline \multirow{2}{*}{$\begin{array}{c}\text { Sr. } \\
\text { No. }\end{array}$} & \multirow{2}{*}{ Tests } & \multicolumn{2}{|c|}{ Results } \\
\cline { 3 - 4 } & Aggregate Impact & Fine Aggregate & Coarse Aggregate \\
\hline & Test & ---- & $20.24 \%$ \\
\hline & $\begin{array}{c}\text { Los Angeles } \\
\text { Abrasion Test }\end{array}$ & \multicolumn{2}{|c|}{$17.19 \%$} \\
\hline & Specific Gravity & 2.73 & 2.87 \\
\hline & Water Absorption & $1.49 \%$ & $2.05 \%$ \\
\hline & & & $\begin{array}{c}1.420 \mathrm{gm} / \mathrm{cc}(10 \\
\mathrm{mm}), \\
\end{array}$ \\
& Bulk Density & $1.657 \mathrm{gm} / \mathrm{cc}$ & $\begin{array}{c}1.455 \mathrm{gm} / \mathrm{cc}(20 \\
\mathrm{mm})\end{array}$ \\
\hline & Flakiness Index & \multicolumn{2}{|c|}{$9.41 \%$} \\
\hline & Elongation Index & \multicolumn{2}{|c|}{$12.80 \%$} \\
\hline
\end{tabular}

Bituminous Binder:

To prepare bituminous concrete, Bitumen used in the study is penetration grade 60/70. Laboratory tests were performed for defining the properties of bitumen and found to be within acceptable limits as per the prevailing standards.

Ceramic waste dust:

In the study two types of filler have been used, the conventional filler i.e. lime and other is ceramic waste. The lime was obtained from local market and the ceramic waste was collected from Morbi Ceramic industrial area, Rajkot, Gujarat, India. Sieve analysis of powdered form ceramic waste and lime was carried out and result shows that $98.5 \%$ of ceramic powder and $58.37 \%$ of lime passed through $75 \mu$ Sieve as per the Indian codal provision (MORT\&H 2012, IS 2386). The chemical properties of the ceramic waste were considered as mentioned [1].

\subsection{Mixture Design and Sample Preparation}

In the study, aggregate grading curve for bitumen mixture were obtained from MORTH Specification (MORT\&H, 2012). Sieve analysis were carried out and obtained grading curve used in the study. Mix design was done according to Marshall Method. Specimens each of 2.5 inch (64 mm) height and 4 inch (102 mm) diameter were prepared at different bitumen content (4.5-7\%) for filler content at 3\% and 5\%. Marshall Test was carried out to find the optimum binder content for both filler (Ceramic waste and lime). Sample Specimens shown in Figure 1 were prepared using Marshall Compactor by giving 75 blows with hammer freefall height of $457 \mathrm{~mm}$ on one side of the mould.

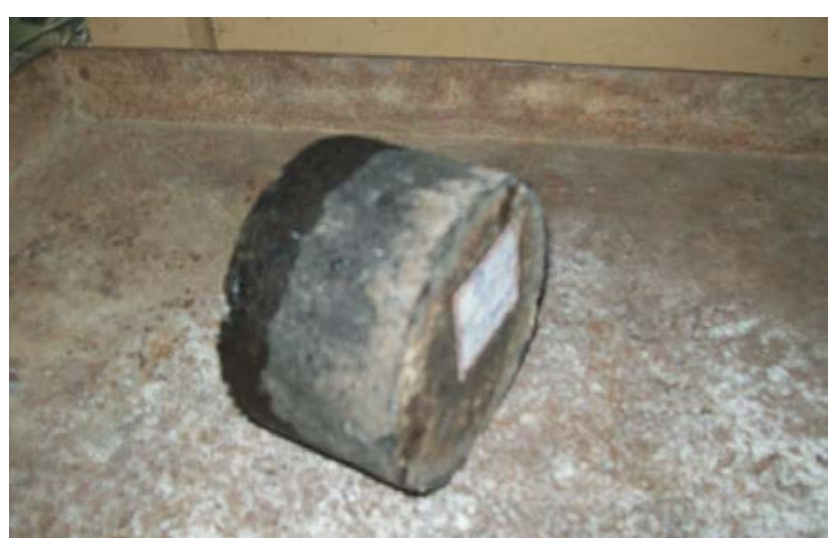

Figure 1. Sample used in test

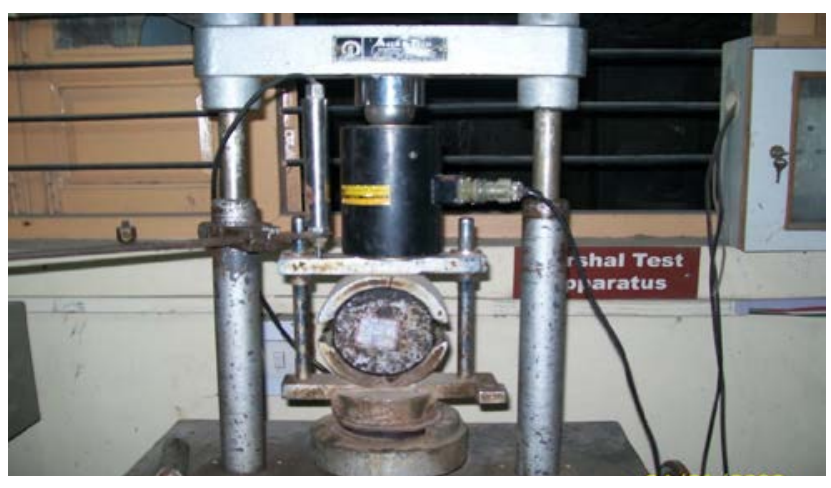

Figure 2. Marshall Test and Stability and Flow Digital Indicator

\subsection{Experimental Investigation}


The Marshall Stability test was carried out using marshall test and stability flow indicator as shown in Figure 2, on four samples each, containing 3\% and 5\% ceramic waste and the other containing 3\% and 5\% lime as filler in the mix design. The stability $(\mathrm{kN})$, unit weight (gm/cc), percentage of air voids present in the sample, flow value measured in $\mathrm{mm}$, percentage of voids filled with bitumen (VFB) and voids in mineral aggregate (VMA) were evaluated on each sample. Results of all the parameters for both ceramic wastes and lime having 3\% and $5 \%$ filler content in the sample are mentioned as in Table 2 \& Table 3.

Table 2. Parameter Obtained for mix (Ceramic Wastes)

\begin{tabular}{|c|c|c|c|c|c|c|c|}
\hline $\begin{array}{l}\text { Ceramic Waste } \\
\text { Content \% }\end{array}$ & $\begin{array}{c}\text { Bitumen } \\
\text { Contents \% }\end{array}$ & $\begin{array}{l}\text { Stability } \\
(1)(\mathrm{kN})\end{array}$ & $\begin{array}{c}\text { Flow } \\
\text { Value(2) } \\
(\mathrm{mm})\end{array}$ & $\begin{array}{c}\text { Air } \\
\text { Voids \%(3) }\end{array}$ & $\begin{array}{c}\text { Voids in Mineral } \\
\text { Aggregates(4) } \\
\text { (VMA) \% }\end{array}$ & $\begin{array}{c}\text { Voids Filled with } \\
\text { Bitumen(5) (VFB) \% }\end{array}$ & $\begin{array}{c}\text { Unit } \\
\text { Weight(6) } \\
\text { gm/cc } \\
\end{array}$ \\
\hline \multirow{6}{*}{$3 \%$} & 4.5 & 10.5 & 3.46 & 5.69 & 15.83 & 64.07 & 2.34 \\
\hline & 5 & 12.6 & 3.50 & 4.71 & 15.96 & 70.46 & 2.38 \\
\hline & 5.5 & 14.01 & 3.56 & 3.38 & 15.76 & 78.58 & 2.49 \\
\hline & 6 & 13.86 & 3.63 & 2.61 & 16.11 & 83.82 & 2.53 \\
\hline & 6.5 & 13.6 & 3.75 & 2.06 & 16.64 & 87.62 & 2.52 \\
\hline & 7 & 11.8 & 4.00 & 1.99 & 17.57 & 88.68 & 2.52 \\
\hline \multirow{6}{*}{$5 \%$} & 4.5 & 12.94 & 3.31 & 6.75 & 16.78 & 59.78 & 2.38 \\
\hline & 5 & 14.52 & 3.38 & 5.27 & 16.51 & 68.10 & 2.44 \\
\hline & 5.5 & 15.84 & 3.52 & 3.59 & 15.95 & 77.50 & 2.49 \\
\hline & 6 & 15.80 & 3.87 & 2.99 & 16.44 & 81.81 & 2.50 \\
\hline & 6.5 & 14.60 & 4.00 & 3.10 & 17.53 & 82.32 & 2.53 \\
\hline & 7 & 11.50 & 4.00 & 2.34 & 17.86 & 86.91 & 2.45 \\
\hline
\end{tabular}

Table 3. Parameter Obtained from mix (Lime)

\begin{tabular}{|c|c|c|c|c|c|c|c|}
\hline $\begin{array}{c}\text { Lime } \\
\text { Content \% }\end{array}$ & $\begin{array}{c}\text { Bitumen } \\
\text { Contents \% } \\
\end{array}$ & $\begin{array}{l}\text { Stability } \\
(\mathrm{kN})\end{array}$ & $\begin{array}{c}\text { Flow Value } \\
(\mathrm{mm})\end{array}$ & $\begin{array}{c}\text { Air } \\
\text { Voids \% } \\
\end{array}$ & $\begin{array}{c}\text { Voids in Mineral } \\
\text { Aggregates (VMA) \% }\end{array}$ & $\begin{array}{l}\text { Voids Filled with } \\
\text { Bitumen (VFB) \% }\end{array}$ & $\begin{array}{c}\text { Unit Weight } \\
\text { gm/cc }\end{array}$ \\
\hline \multirow{6}{*}{$3 \%$} & 4.5 & 13.24 & 3.33 & 5.58 & 15.73 & 64.54 & 2.44 \\
\hline & 5 & 13.90 & 3.42 & 3.82 & 15.17 & 74.81 & 2.48 \\
\hline & 5.5 & 13.71 & 3.91 & 3.73 & 16.07 & 76.77 & 2.53 \\
\hline & 6 & 12.86 & 3.98 & 2.76 & 16.24 & 82.98 & 2.51 \\
\hline & 6.5 & 11.48 & 4.00 & 2.75 & 17.23 & 84.03 & 2.48 \\
\hline & 7 & 11.20 & 4.00 & 2.21 & 17.75 & 87.56 & 2.47 \\
\hline \multirow{6}{*}{$5 \%$} & 4.5 & 12.2 & 3.40 & 9.45 & 19.11 & 50.57 & 2.38 \\
\hline & 5 & 13.5 & 3.52 & 6.90 & 17.80 & 61.23 & 2.47 \\
\hline & 5.5 & 14.5 & 3.58 & 3.42 & 15.71 & 78.20 & 2.54 \\
\hline & 6 & 14.3 & 3.68 & 2.09 & 15.56 & 86.54 & 2.52 \\
\hline & 6.5 & 13.4 & 3.75 & 2.27 & 16.71 & 86.39 & 2.50 \\
\hline & 7 & 11.8 & 4.00 & 2.15 & 17.58 & 87.79 & 2.49 \\
\hline
\end{tabular}

Table 4. Marshall Parameter

\begin{tabular}{|c|c|c|c|c|c|c|}
\hline \multirow{2}{*}{ Sr. No } & \multirow{2}{*}{ Marshall Parameters } & \multirow{2}{*}{ Specified Range MORT\&H 2012} & \multicolumn{4}{|c|}{ Obtained Values at OBC } \\
\hline & & & $3 \% \mathrm{CW}$ & $5 \% \mathrm{CW}$ & $3 \% \mathrm{~L}$ & $5 \% \mathrm{~L}$ \\
\hline 1. & Stability (kN) & Minimum 9kN & 13.93 & 15.92 & 13.88 & 14.43 \\
\hline 2. & Unit Weight gm/cc & - & 2.48 & 2.51 & 2.50 & 2.52 \\
\hline 3. & Air Voids \% & $3-5$ & 4.89 & 4.98 & 4.46 & 4.24 \\
\hline 4. & Flow Value (mm) & $2-4$ & 3.55 & 3.73 & 3.64 & 3.58 \\
\hline 5. & VFB \% & $75-85$ & 79.20 & 79.40 & 74.67 & 75.99 \\
\hline 6. & VMA\% & Minimum 13\% & 15.85 & 16.37 & 15.46 & 16.22 \\
\hline
\end{tabular}

The Table 2 \& Table 3 shows the effect of the ceramic waste as a filler and the conventional filler effect on various parameters such as Stability, Flow Value, Air Voids, Voids in Mineral Aggregates, Voids Filled with Bitumen and unit weight at different binder content.

\section{Results and Discussion}

The Optimum Binder Content (OBC) for specimens containing $3 \%$ and $5 \%$ ceramic waste $(\mathrm{CW})$ was estimated to be $5.57 \%$ and $5.80 \%$ respectively and that for the sample containing $3 \%$ and $5 \%$ lime (L) came out to be $5.18 \%$ and $5.49 \%$ respectively. This clearly indicates the similarities between ceramic waste and lime. Results are incrasing and may be used to ceramic can replace lime. The results of the Marshall Test parameters obtained at OBC value for all the 4 types of samples are shown in Table 4.

It was noted that the ceramic wastes meet all minimum requirements as per MORTH 2012 Specification as a filler material in SDBC.

\subsection{Optimum Binder Content (OBC) Requirement for Ceramic Waste \& Lime}

The estimated OBC values for ceramic filler $(5.57 \%$ $5.80 \%)$ is higher than that of lime (5.18\%-5.49\%) at both $3 \%$ and $5 \%$ filler content. The higher requirement of binder in mixes with ceramic waste as filler might be due to the larger surface per unit volume and greater absorption of binder by ceramic waste.

\subsection{Marshall Stability}

Marshall Stability values are higher in case of ceramic filler at both $3 \%$ and $5 \%$ filler content. The stability values for the ceramic waste as filler is highest among all at 5\% filler content and about $10 \%$ higher than conventional filler (lime). Figure 3 shows that the stability value increases till the addition of 5\% and 5.5\% bitumen content in $3 \%$ and $5 \%$ lime mixes respectively and then decreases rapidly. 


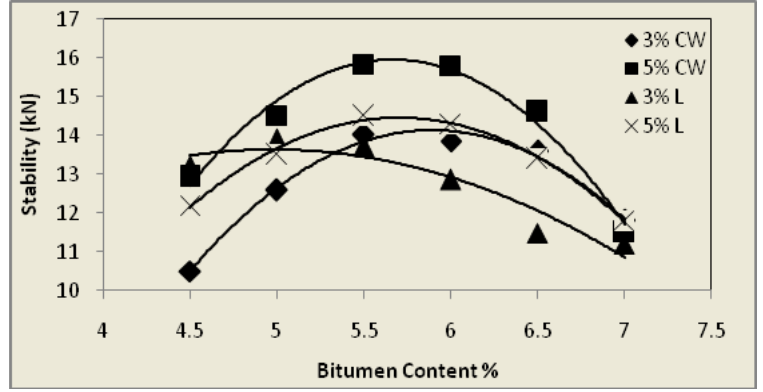

Figure 3. Marshall Stability of Ceramic Waste and Lime

Marshall Stability values are higher in case of ceramic filler at both $3 \%$ and $5 \%$ filler content. The stability values for the ceramic waste as filler is highest among all at 5\% filler content and about $10 \%$ higher than conventional filler (lime). Figure 3 shows that the stability value increases till the addition of 5\% and 5.5\% bitumen content in $3 \%$ and $5 \%$ lime mixes respectively and then decreases rapidly.

\subsection{Flow values}

The flow values of $3 \%$ and $5 \%$ filler content of the mixes of both materials are within the limits. Ceramic waste mixes show continuous increase in flow values but mixes with lime show an uneven increase in case of $3 \%$ filler content while reverse is true for $5 \%$ filler. The results obtained shows that ceramic waste will deform more under the traffic loads and will have more flexibility. The flow values obtained at OBC brought out a different picture. The flow values obtained at $3 \%$ filler reveals that the flow value of CW (3.55 mm) is less than that of the lime $(3.64 \mathrm{~mm})$. As the filler content is increased to $5 \%$, the parameter increases to $3.73 \mathrm{~mm}$ in case of $\mathrm{CW}$ and decreases to $3.58 \mathrm{~mm}$ in case of Lime. However, both 3\% and $5 \% \mathrm{CW}$ as filler can be used in SDBC at OBC as shown in Figure 4.

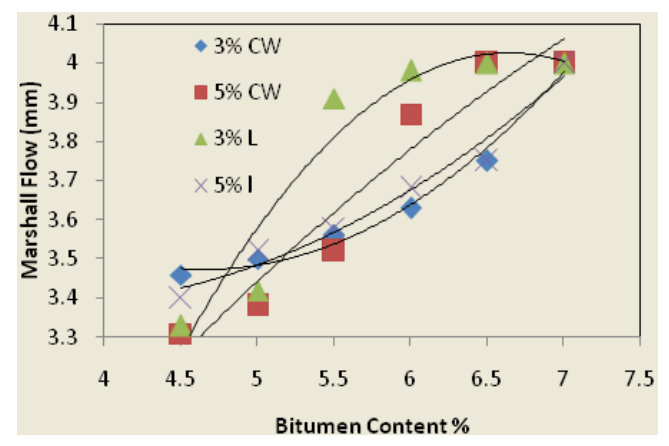

Figure 4. Marshall Flow of Lime and Ceramic Waste

The flow values of $3 \%$ and $5 \%$ filler content of the mixes of both materials are within the limits. Ceramic waste mixes show continuous increase in flow values but mixes with lime show an uneven increase in case of $3 \%$ filler content while reverse is true for $5 \%$ filler. The results obtained shows that ceramic waste will deform more under the traffic loads and will have more flexibility.

The flow values obtained at OBC brought out a different picture. The flow values obtained at 3\% filler reveals that the flow value of $\mathrm{CW}(3.55 \mathrm{~mm})$ is less than that of the lime $(3.64 \mathrm{~mm})$. But, as the filler content is increased to $5 \%$, the parameter increases to $3.73 \mathrm{~mm}$ in case of $\mathrm{CW}$ and decreases to $3.58 \mathrm{~mm}$ in case of Lime.
But, both 3\% and 5\% CW as filler can be used in SDBC at OBC.

\subsection{Air Voids}

Table 4 \& 5 indicates that the percentage of air voids in the mix decreases for both mixes as the bitumen content increases. This is expected since the bitumen will fill the voids in the aggregate matrix. According to MORT\&H criteria, voids in the mix must range from $2 \%$ to $4 \%$. It can be seen that for the range of bitumen content of $4.5 \%$ to $7 \%$, the voids are within the specified limits (MORT\&H 2013) [17]. Both lime and CW fillers have air voids within the limits of 3-5\%. Hence, both can be used for SDBC as shown in Figure 5.

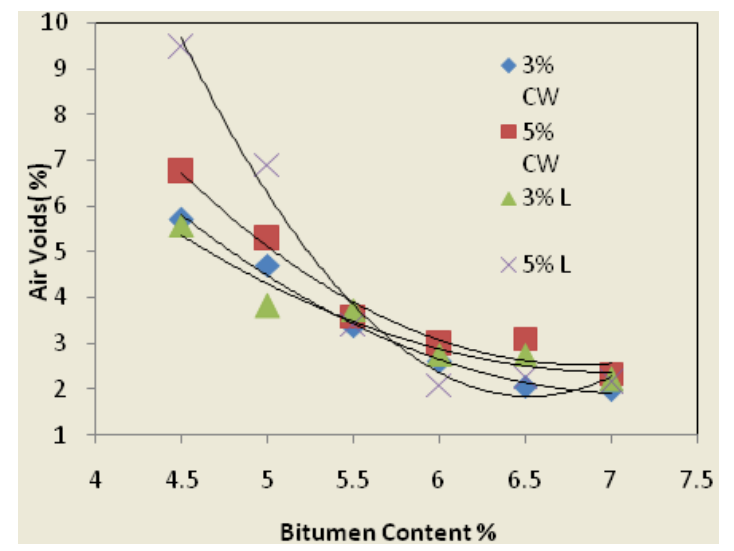

Figure 5. Effect of Ceramic Waste and Lime on the voids of asphalt mix

\subsection{Unit Weight}

For all the samples, the maximum compacted density attained is almost the same (2.53 $\mathrm{gm} / \mathrm{cc})$. Moreover, the density increases till its maxima and then decreases for all mixes. But, lime has slightly greater density than $\mathrm{CW}$ for both $3 \%$ and $5 \%$ filler content obtained at OBC as shown in Figure 6.

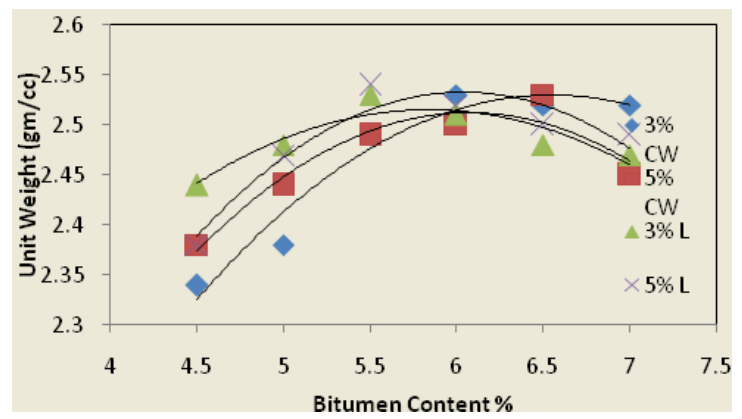

Figure 6. Effect of Ceramic Waste and Lime on compacted density of mix

\section{Conclusions}

The higher order roads like National highway, State Highway and Major Urban Arterials and Sub Arterials posses the bituminous concrete at the top and need filler contents. Generally, lime, cement or fine dusts are used. As ceramic industries produce ceramic powder as waste in huge quantity, it necessitates the disposal of such materials. The alternate option is to use it in construction activities. 
This study focuses on a laboratory evaluation of the mechanical performance of asphalt concrete mixes using Ceramic Waste as filler. A comparative study is carried out here for two different filler materials i.e. lime and Ceramic powder. The Marshall tests were conducted on the bituminous mixes containing 3-5\% ceramic waste \& lime. Based on the laboratory experiments and analysis, the following conclusions are drawn.

1. It is observed that with the increase in Ceramic Waste content from 3 to $5 \%$, the stability value increases by $14.29 \%$ and the stability increases by $3.96 \%$ for lime filler.

2. On comparison between Ceramic Waste and Lime, it is found that Marshall Stability of Ceramic mix is $10.32 \%$ greater than that of Lime mix at 5\% filler content.

3. The patterns obtained in the flow values indicates that ceramic waste will deform more under the traffic loads and will have more flexibility.

4. The flow values for both $3 \%$ and $5 \% \mathrm{CW}$ filler satisfy the limits and hence can be used in SDBC as filler.

5. Ceramic waste satisfies the entire minimum requirement for mineral filler specified in the MORTH bituminous concrete mixture.

It was concluded that ceramic industrial waste can be utilized as a replacement for conventional mineral fillers in bituminous mixes. The utilization of ceramic waste in the asphalt concrete mixes may solve the significant disposal problem to save the environment.

\section{References}

[1] Electricwala Fatima, Ankit Jhamb, Rakesh Kumar (2013) 'Ceramic Dust as Construction Material in Rigid Pavement', American Journal of Civil Engineering and Architecture 1 (5), 112-116.
[2] Hanifi Binici, (2007) 'Effect of crushed ceramic and basaltic pumice as fine aggregates on concrete mortars properties', Construction and Building Materials 21, 1191-1197.

[3] F. Pacheco-Torgal, S. Jalali "Reusing ceramic wastes in concrete (2010) 'Construction and Building Materials', 24: 832-838.

[4] C. Medina, M.I. Sanchez de Rojas, M. Frias (2012) 'Reuse of sanitary ceramic wastes as coarse aggregate in eco-efficient concrete', Cement \& Concrete Composites 34, 48-54.

[5] Diana Movilla-Quesada, Ángel Vega-Zamanillo, Miguel Ángel Calzada-Pérez, Daniel Castro-Fresno (2012) 'Evaluation of water effect on bituminous mastics with different contribution fillers and binders', Construction and Building Materials, 29, 339-347.

[6] Baoshan Huang, Qiao Dong, Edwin G. Burdette (2009) 'Laboratory evaluation of incorporating waste ceramic materials into portland cement and asphaltic concret', Construction Building Materials 23, 3451-3456.

[7] Nuran Ay, Mevlut Unal (2000) 'The use of waste ceramic tile in cement production', Cement and Concrete Research 30, 497-499.

[8] Mehmet Gesoğlu, Erhan Güneyisi, Mustafa E. Kocabağ, Veysel Bayram, Kasım Mermerdaş (2012) 'Fresh and hardened characteristics of self compacting concretes made with combined use of marble powder, limestone filler, and fly ash', Construction and Building Materials, 37, 160-170.

[9] Hüseyin Akbulut, Cahit Gürer, Sedat Çetin, Ayfer Elmacı (2012) 'Investigation of using granite sludge as filler in bituminous hot mixtures’, Construction and Building Materials, 36, 430-436.

[10] Om prakash Yadav, Manjunath K.R. (2012) 'Cold Mix Design of Semi-Dense Bituminous Concrete’, IOSR Journal of Mechanical and Civil Engineering, 1 (6), 09-16.

[11] N K S Pundhir, C Kamaraj, P K Nanda (2005) 'Use of Copper Slag as Construction Material in Bituminous Pavements', Journal of Scientific and Industrial Research, 64, 997-1002.

[12] Moncef Nehdi (2000) 'Why some carbonate fillers cause rapid increases of viscosity in dispersed cement-based materials', Cement and Concrete Research, 30 (10), 1663-1669.

[13] İsmail Uzun, Serdal Terzi (2012) 'Evaluation of andesite waste as mineral filler in asphaltic concrete mixture', Construction and Building Materials, 31, 284-288.

[14] IS: 2386, (2007) 'Indian Standard Method of Test for Aggregates for Concrete', BIS, New Delhi.

[15] BIS 12269: (1987) 'Specification for 53 grade ordinary Portland cement', 5th Revision, BIS, New Delhi.

[16] MORT\&H (2013) 'Ministry of Road Transportation and Highway (Fifth Revision)'. 